\title{
Effect of nitrogen and sulfur on weed infestation and rapeseed productivity
}

\author{
Shafiullah ${ }^{1 *}$, Fazal Munsif ${ }^{2}$, Arshad Ali $^{2}$, Jan E Alam², Sayyad Khan ${ }^{2}$, \\ Haseeb Ahmad Kakar ${ }^{1}$, Shah Fahad ${ }^{1}$ and Rashid Jalal ${ }^{1}$ \\ 1. Department of Agronomy, The University of Agriculture, Peshawar, Khyber Pakhtunkhwa-Pakistan \\ 2. Department of Agronomy, The University Agric. Peshawar, Amir Muhammad Khan Campus Mardan-Pakistan \\ *Corresponding author's email: shafi@aup.edu.pk \\ Citation \\ Shafiullah, Fazal Munsif, Arshad Ali, Jan E Alam, Sayyad Khan, Haseeb Ahmad Kakar, Shah Fahad and Rashid \\ Jalal. Effect of nitrogen and sulfur on weed infestation and rapeseed productivity. Pure and Applied Biology. Vol. 7, \\ Issue 1, pp321-329. http://dx.doi.org/10.19045/bspab.2018.70039
}

\begin{tabular}{llll}
\hline Received: $30 / 11 / 2017$ & Revised: $19 / 02 / 2018$ & Accepted: 22/02/2018 & Online First: 28/02/2018 \\
\hline
\end{tabular}

\section{Abstract}

Nutrient management over a wide range is the major agronomic practices to reduce weeds infestation and increasing rapeseed productivity. Weeds compete with crop for some resources i.e. light, water, nutrients and space, causing serious damage to crop by reducing crop yield and net return. Hence the experiment was conducted at Plato research farm, Amir Muhammad khan campus Mardan, The University of Agriculture Peshawar during rabi 2015-16 to study the effect of $\mathrm{N}$ and $\mathrm{S}$ on weed infestation and yield of rapeseed. The trail was laid out in randomized complete block design replicated three times. Cv. Zahoor was used as a test crop. The experimental treatments include two levels of $\mathrm{N}$ i.e. 75 and $125 \mathrm{~kg} \mathrm{ha}^{-1}$ and two levels of sulfur i.e. 15 and $30 \mathrm{~kg} \mathrm{ha}^{-1}$ along with one control treatment. Results of the study indicated that yield as well as weeds infestation were significantly affected by various levels of $\mathrm{S}$ and $\mathrm{N}$. Increments in $\mathrm{N}$ fertilization resulted maximum seed yield, biological yield, $\mathrm{HI}$ and also increases weeds infestation. Higher yield of rapeseed was recorded with $30 \mathrm{~kg} \mathrm{~S}^{-1}$ along with $125 \mathrm{~kg} \mathrm{~N} \mathrm{ha}^{-1}$. This study revealed that the competitive ability of rapeseed against weeds may enhance with the use of optimum levels of S and $\mathrm{N}$.

Keywords: Nitrogen; Sulfur; Seed yield; Weeds density; Weeds biomass

\section{Introduction}

Rapeseed (Brassica napus L.) is a famous member of family Cruciferae with about 160 species within Brassica. It is a rapid growing crop of rabi season and its leaves are utilized as vegetables. In Pakistan it is grown for fodder purpose as well as serves as a source of edible oil. Edible oil is one of the basic and major requirements of our daily diet. Pakistan is encountered with a deficiency of edible oil because of its high consumption about 2.325 million tons while only 0.606 million tones met through country production while the rest is imported every year [1]. There is a critical demand for increasing oilseed production. In this regard rapeseed can be grown successfully in Pakistan, because it suits to the agroecological condition of the country very well. Lower seed yield of rapeseed is due to some major constraint i.e. adoptable cultivars, agronomic practices and the availability of nutrients in proper amount. Management of nitrogen for almost all the crops is important. Excessive nitrogen application to rapeseed increases the risk of 
lodging and thus the yield is adversely affected, suboptimal application of $\mathrm{N}$ limited the crop growth. Nitrogen $(\mathrm{N})$ requirement of rapeseed is high as compare to cereals crops. It is available to the plants in the form of ammonium or nitrate. Crop yield may be boast up with nitrogen fertilization $[2,3]$. Excessive use of nitrogen reduces grain yield and quality of rapeseed [4].Optimum nitrogen fertilization leads a rapid growth of the plant canopy and greatly contributes to word grain filling [5]. [6] recorded that productivity of rapeseed boast with increments in nitrogen application up to 100 $\mathrm{kg} \mathrm{ha}{ }^{-1}$. [7] Concluded that increments in nitrogen application increases seed yield of rapeseed. Sulfur is the fourth major macro nutrient after nitrogen, phosphorous and potassium. It plays a key role in protein synthesis and chlorophyll formation. It is required for the development of fertile flowers on rapeseed plants. In rapeseed, sulfur deficiency symptoms begin with initial stage of one leaf, as the color of the young leaves turning yellowish green with dark vein coloration and plants result in pale yellow color with stunted growth. Weeds interfere with crop for resources i.e. light, water, nutrients and space causing serious damage to crop. Weeds reduced grain yields and quality and cause a considerable cost to farmers. Weeds compete with the crops for different environmental resources and either inhibit or stimulate the crop growth by releasing allele chemicals into the environment. Grain yield represent the Competitiveness of crop with weeds. Maximum yield in the presence of weeds represent crop competitive ability, and weed suppression. To determine the damage caused by the weeds several parameters were studied like weed density, species, duration and area of influence.

Keeping in view the importance of sulfur and nitrogen application for proper management of weeds in rapeseed and enhancing seed yield, the present research was conceptualized to find out the most optimum level of nitrogen and sulfur for proper weeds management.

\section{Materials and methods}

The experiment was carried out to examine rapeseed yield and weed density affected by $\mathrm{N}$ and $\mathrm{S}$ at Palatoo Research Farm (PRF), the University of Agriculture Peshawar, Amir Muhammad khan campus during Rabi 201516. The experiment was consisted of two nitrogen i.e 75 and $125 \mathrm{~kg} \mathrm{ha}^{-1}$ and sulfur i.e 15 and $30 \mathrm{~kg} \mathrm{ha}^{-1}$. The experiment was carried out in randomized complete block design with four replications. Seeds of rapeseed $\mathrm{cv}$. Zahoor were sown at the rate of $5 \mathrm{~kg} \mathrm{ha}^{-1}$ on $17^{\text {th }}$ November, 2015. The plots size was $2 \mathrm{~m} \times 1.3 \mathrm{~m}$ having four rows $1.3 \mathrm{~m}$ long and $50 \mathrm{~cm}$ apart. Phosphorous was applied at the rate of $60 \mathrm{~kg} \mathrm{ha}^{-1}$ from SSP fertilizer at sowing time as basal dose. Urea and ammonium sulphate was utilized as a source for nitrogen and sulfur fertilization. The $\mathrm{N}$ applied from ammonium sulphate was adjusted from the urea. The entire $\mathrm{P}$ was applied at sowing time while half $\mathrm{S}$ and $\mathrm{N}$ were applied at sowing and half at rosette stage. Irrigation of crop was done according to the environmental condition and crop water requirement.

\section{Data recording procedure}

Weeds density was recorded in one meter row length at three random places in each plot, uprooted weeds were count, averaged and converted in to $\mathrm{m}^{-2}$. Similar species of uprooted weeds were separated and weighed with electronic balance and then converted in to $\mathrm{g} \mathrm{m}^{-2}$ to record data on weeds fresh biomass. For weed dry biomass $\left(\mathrm{g} \mathrm{m}^{-2}\right)$ data, the uprooted weeds from each plot were oven dried at $720 \mathrm{c}$ for 24 hours and weighed with electronic balance. Central two rows were harvested from each plot using a sickle and sun dried for 10 days and weight with electronic balance to record data on biological yield. The harvested rows 
were threshed, the grains collected weighted with electronic balance and then converted into $\mathrm{kg} \mathrm{ha}^{-1}$. Harvest index was determined as the ratio of grain yield to biological yield. Statistical Analysis

The data were subjected to analysis of variance using $\mathrm{F}$ test suitable for randomized complete block design were used for analysis of collected data. LSD test at $5 \%$ confidence interval were used for comparing treatments means.

\section{Results}

Weeds density $\left(\mathrm{m}^{-2}\right)$

Data on weeds density $\mathrm{m}^{-2}$ in (Table 1 ) indicated non-significant affect of sulfur, while nitrogen had significantly influenced the density of $F$. indica, while the density of $E$. helioscopia and $R$. dentatus did not differ significantly with increments in $\mathrm{N}$ application. Control vs. rest was found significant. The interaction between sulfur and nitrogen was found non-significant for density of all identified weeds ( $F$. indica and $R$. dentatus E. heliscopia). Highest density of $F$. indica (28.3) was found with the application of $125 \mathrm{~kg} \mathrm{ha}^{-1}$. Density of $F$. indica in control plots (22.5) is lower as compared to treated plots (26.7).

Table 1. Weed density $\left(\mathrm{m}^{-2}\right)$ of $F$. indica, E. helioscopia and $R$. dentatus of rapeseed as influenced by nitrogen and sulfur

\begin{tabular}{|c|c|c|c|}
\hline Nitrogen $\left(\mathrm{kg} \mathrm{ha}^{-1}\right)$ & F. indica $\left(\mathrm{m}^{-2}\right)$ & E. helioscopia $\left(\mathrm{m}^{-2}\right)$ & R. dentatus $\left(\mathrm{m}^{-2}\right)$ \\
\hline 75 & 25.1 & 24.6 & 24.7 \\
\hline 125 & 28.3 & 24.8 & 26.2 \\
\hline Significance & $*$ & Ns & Ns \\
\hline \multicolumn{4}{|l|}{ Sulfur $\left(\mathrm{kg} \mathrm{ha}^{-1}\right)$} \\
\hline 15 & 26.4 & 25.0 & 25.9 \\
\hline 30 & 27.0 & 24.4 & 25.0 \\
\hline Significance & Ns & Ns & Ns \\
\hline Control & 22.5 & 21.8 & 22.8 \\
\hline Rest & 26.7 & 24.7 & 25.4 \\
\hline Significance & $*$ & Ns & Ns \\
\hline $\mathrm{NxP}$ & Ns & $\mathrm{Ns}$ & $\mathrm{Ns}$ \\
\hline
\end{tabular}

\section{Weeds Fresh Biomass $\left(\mathrm{g} \mathrm{m}^{-2}\right)$}

Statistical analysis of the data regarding weeds fresh biomass in (Table 2) revealed that sulfur significantly affect fresh biomass of all identified weeds except E. helioscopia, where significant affect of nitrogen was observed on weeds fresh biomass. Planed mean comparison shows that weeds fresh biomass in control plots was significantly lower as compared to fertilized plots. Maximum fresh biomass of $F$. indica, $E$. helioscopia and $R$. dentatus (200.0, 222.5 and $197.5 \mathrm{~m} \mathrm{~g} \mathrm{~m}^{-2}$ ), respectively were observed in the plots fertilized with $125 \mathrm{~kg}$ $\mathrm{N} \mathrm{ha}{ }^{-1}$. The interaction between sulfur and nitrogen was found significant for all identified weeds except E. helioscopia. Sulfur application at the rate of $30 \mathrm{~kg} \mathrm{ha}^{-1}$ results maximum fresh biomass of $F$. indica. Weeds Dry Biomass $\left(\mathrm{g} \mathrm{m}^{-2}\right)$

Data on weeds dry biomass of are presented in Table 3. Statistical analysis of the data indicated that sulfur had no significant impact on dry biomass of all identified weeds, while nitrogen significantly affects dry biomass of $F$. indica, $R$. dentatus and $E$. helioscopia. Planed mean comparison shows that control vs. rest was found significant. Dry biomass of $F$. indica, E. helioscopia and $R$. dentatus in control plots $(20.2,20.8$ and $19.0 \mathrm{~g} \mathrm{~m}^{-2}$ ) is significantly lower as compare to fertilize plots $\left(27.9,28.3\right.$ and $\left.27.5 \mathrm{~g} \mathrm{~m}^{-2}\right)$. 
The interaction between sulfur and nitrogen was found significant in all identified weeds. Maximum dry biomass of $F$. indica, $E$. helioscopia and $R$. dentatus $(29.7,30.3$ and $29.3 \mathrm{~g} \mathrm{~m}^{-2}$, respectively) were observed with the application of $125 \mathrm{~kg} \mathrm{~N} \mathrm{ha}^{-1}$.

Table 2. Fresh weight $\left(\mathrm{g} \mathrm{m}^{-2}\right)$ of $F$. indica, $E$. helioscopia and $R$. dentatus of rapeseed as affected by nitrogen and sulfur

\begin{tabular}{|c|c|c|c|}
\hline Nitrogen $\left(\mathbf{k g ~ h a}^{-1}\right)$ & $\boldsymbol{F}$. indica $\mathbf{( g )}$ & $\boldsymbol{E}$. helioscopia $\mathbf{( g )}$ & $\boldsymbol{R}$. dentatus $(\mathbf{g})$ \\
\hline 75 & 177.4 & 205.8 & 177.0 \\
\hline 125 & 200.3 & 222.5 & 197.5 \\
\hline Significance & $*$ & $*$ & $*$ \\
\hline Sulfur $\left(\mathrm{kg} \mathrm{ha}^{-1}\right)$ & & & \\
\hline 15 & 178.5 & 211.9 & 177.4 \\
\hline 30 & 199.2 & 216.4 & 197.0 \\
\hline Significance & $*$ & Ns & $*$ \\
\hline Control & 143.2 & 153.5 & 110.3 \\
\hline Rest & 188.8 & 214.2 & 187.2 \\
\hline Significance & $*$ & $*$ & $*$ \\
\hline NxP & $*$ (figure 1$)$ & Ns & $*$ (figure 2) \\
\hline
\end{tabular}

$$
\begin{array}{r}
250.0 \\
200.0 \\
150.0 \\
100.0 \\
50.0 \\
0.0
\end{array}
$$

$75 \mathrm{kgN}$

$125 \mathrm{kgN}$

$15 \mathrm{~kg} \mathrm{~S}$

$30 \mathrm{Kg} \mathrm{S}$

Figure 1. Interaction between sulfur and nitrogen for fresh weight of $R$. dentatus

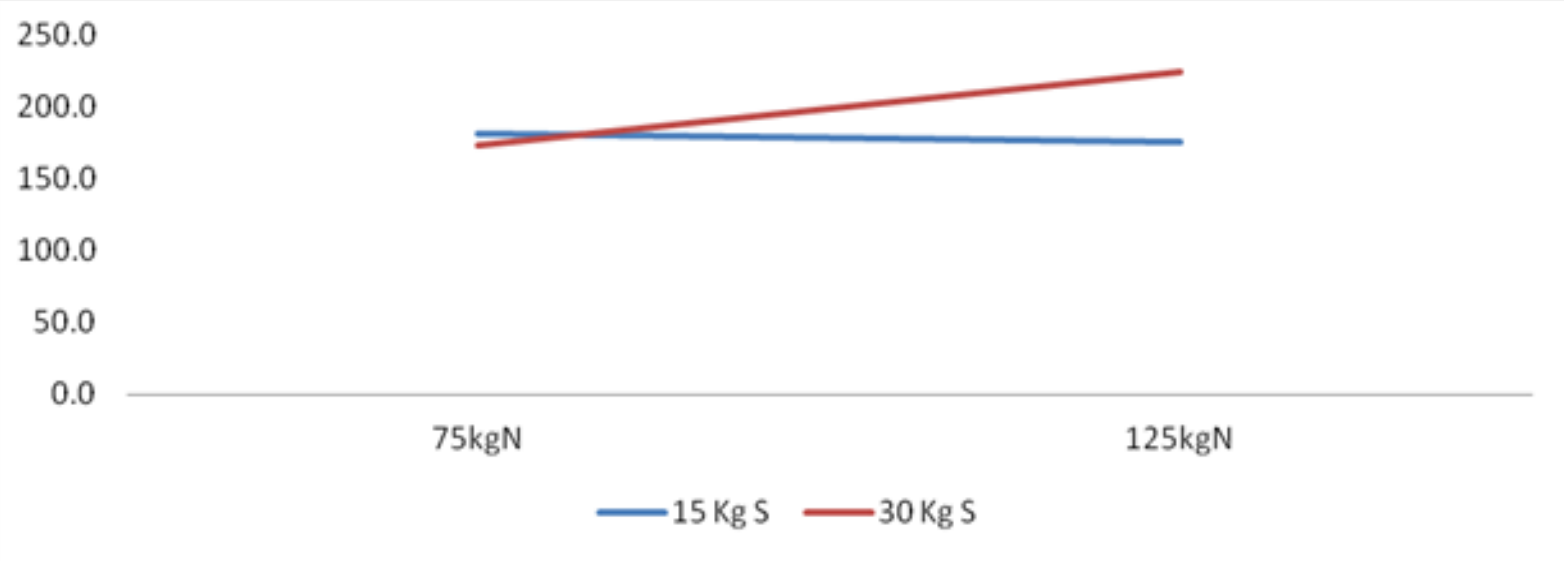

Figure 2. Interaction between sulfur and nitrogen for fresh weight of $F$. indica 
Table 3. Dry weight $\left(\mathrm{g} \mathrm{m}^{-2}\right)$ of $F$. indica, E. helioscopia and $R$. dentatus of rapeseed as affected by nitrogen and sulfur.

\begin{tabular}{|c|c|c|c|}
\hline Nitrogen $\left(\mathbf{k g ~ h a}^{-1}\right)$ & F. indica $(\mathbf{g})$ & E. helioscopia $(\mathbf{g})$ & R. dentatus $(\mathbf{g})$ \\
\hline 75 & 26.0 & 30.3 & 25.4 \\
\hline 125 & 29.7 & 26.4 & 29.3 \\
\hline Significance & $*$ & $*$ & $*$ \\
\hline Sulfur $\left(\mathrm{kg} \mathrm{ha}^{-1}\right)$ & & & 28.4 \\
\hline 15 & 27.2 & 29.8 & 26.3 \\
\hline 30 & 28.5 & $\mathrm{Ns}$ & $\mathrm{Ns}$ \\
\hline Significance & $\mathrm{Ns}$ & 20.8 & 19 \\
\hline Control & 12.7 & 28.3 & 27.3 \\
\hline Rest & 27.9 & $*$ & $*$ \\
\hline Significance & $*$ & $*($ figure 4) & $\mathrm{Ns}$ \\
\hline NxP & $*($ figure3) & & \\
\hline
\end{tabular}

35.0
30.0
25.0
20.0
15.0
10.0
5.0
0.0

$75 \mathrm{kgN}$

$125 \mathrm{kgN}$

$-15 \mathrm{Kg} \mathrm{S}-30 \mathrm{Kg} \mathrm{S}$

Figure 3. Interaction between sulfur and nitrogen for dry weight of $F$. indica

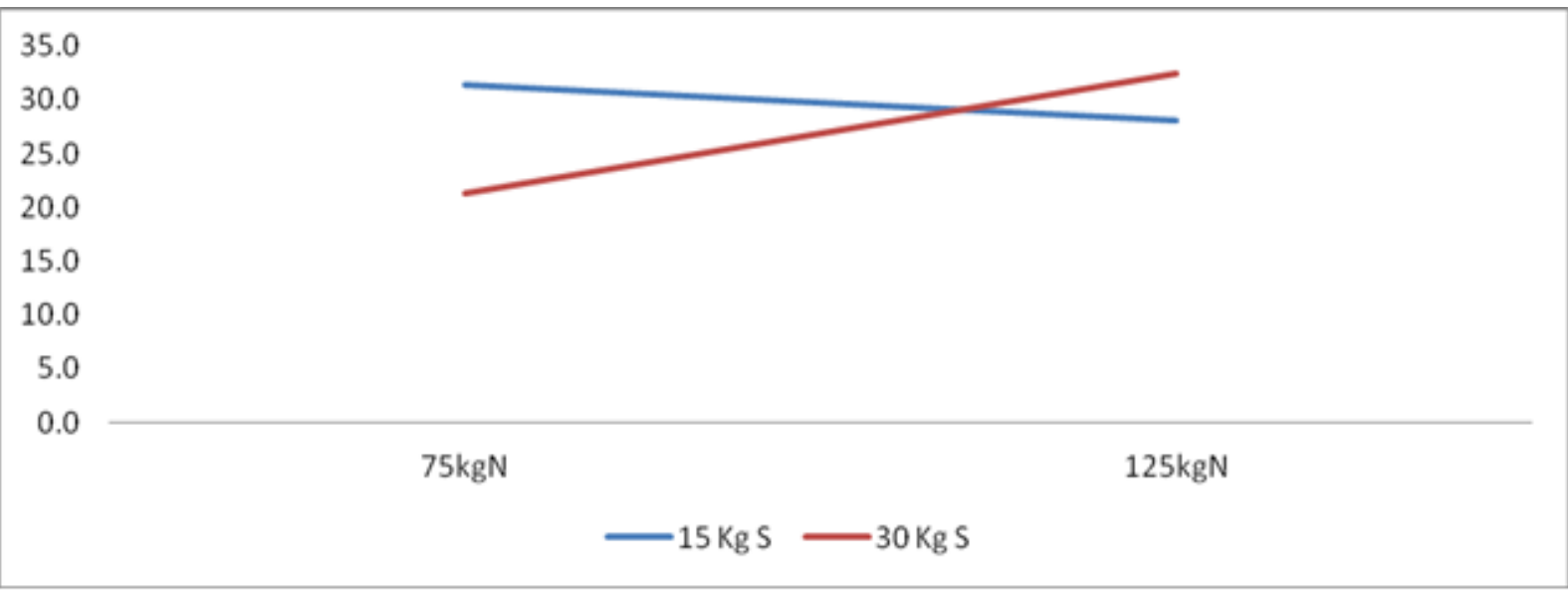

Figure 4. Interaction between sulfur and nitrogen for dry weight of $E$. helioscopia 


\section{Biological yield ( $\left.\mathrm{kg} \mathrm{ha}^{-1}\right)$}

Biological yield was considerably affected by the different doses of nitrogen and sulfur, however their interaction was found non significant (Table 2). Maximum biological yield $\left(8380.6 \mathrm{~kg} \mathrm{ha}^{-1}\right)$ was recorded in the plots applied with $125 \mathrm{~kg} \mathrm{~N} \mathrm{ha}^{-1}$ as compare to75 $\mathrm{kg} \mathrm{N}^{-1}{ }^{-1}$ which is $\left(7372.2 \mathrm{~kg} \mathrm{ha}^{-1}\right)$. The recorded data revealed that biological yield was increased as the rate of $\mathrm{S}$ was increased from 15 to $30 \mathrm{~kg} \mathrm{ha}^{-1}$. The control plots resulted in lesser biological yield $(6562.4 \mathrm{~kg}$ $\mathrm{ha}^{-1}$ ) as compared to fertilized plots (7876.4 $\mathrm{kg} \mathrm{ha}^{-1}$ )

\section{Seed Yield $\left(\mathrm{kg} \mathrm{ha}^{-1}\right)$}

Statistical analysis of the data in (Table 4) indicated that nitrogen and sulfur had significant impact seed yield of rapeseed. The interaction between sulfur and nitrogen was found significant. Control vs rest was also found significant. Increments in nitrogen application boast the seed yield of rapeseed. Seed yield in control plots (1363.8 $\mathrm{kg} \mathrm{ha}^{-1}$ ) was lowered as compared to the rest of treatments $\left(1818.2 \mathrm{~kg} \mathrm{ha}^{-1}\right)$. Maximum seed yield $\left(1882.5 \mathrm{~kg} \mathrm{ha}^{-1}\right)$ was observed in the plots treated with $30 \mathrm{~kg} \mathrm{ha}^{-1}$ of sulfur application.

Table 4. Seed yield, biological yield and harvest index of rapeseed as affected by nitrogen and sulfur.

\begin{tabular}{|c|c|c|c|}
\hline Nitrogen $\left(\mathbf{k g ~ h a}^{-\mathbf{1}}\right)$ & Seed yield $\left(\mathbf{k g ~ h a}^{-\mathbf{1}}\right)$ & $\begin{array}{c}\text { Biological yield (kg ha- } \\
\mathbf{1})\end{array}$ & $\begin{array}{c}\text { Harvest index } \\
(\mathbf{\%})\end{array}$ \\
\hline 75 & 1694.1 & 7372.2 & 23.9 \\
\hline 125 & 2004.2 & 8319.6 & 26.1 \\
\hline Significance & $*$ & $*$ & $*$ \\
\hline Sulfur $\left(\mathrm{kg} \mathrm{ha}^{-1}\right)$ & & & 24.1 \\
\hline 15 & 1766.4 & 7480 & 25.9 \\
\hline 30 & 1931.9 & 8211.9 & Ns \\
\hline Significance & $*$ & $*$ & 15.9 \\
\hline Control & 903.1 & 5895.7 & 25.0 \\
\hline Rest & 1849.2 & 7845.9 & $*$ \\
\hline Significance & $*$ & $*$ & $*$ (figure 6) \\
\hline NxP & $*$ (figure 5) & Ns & \\
\hline
\end{tabular}

*= significant, $\mathrm{ns}=$ non-significant

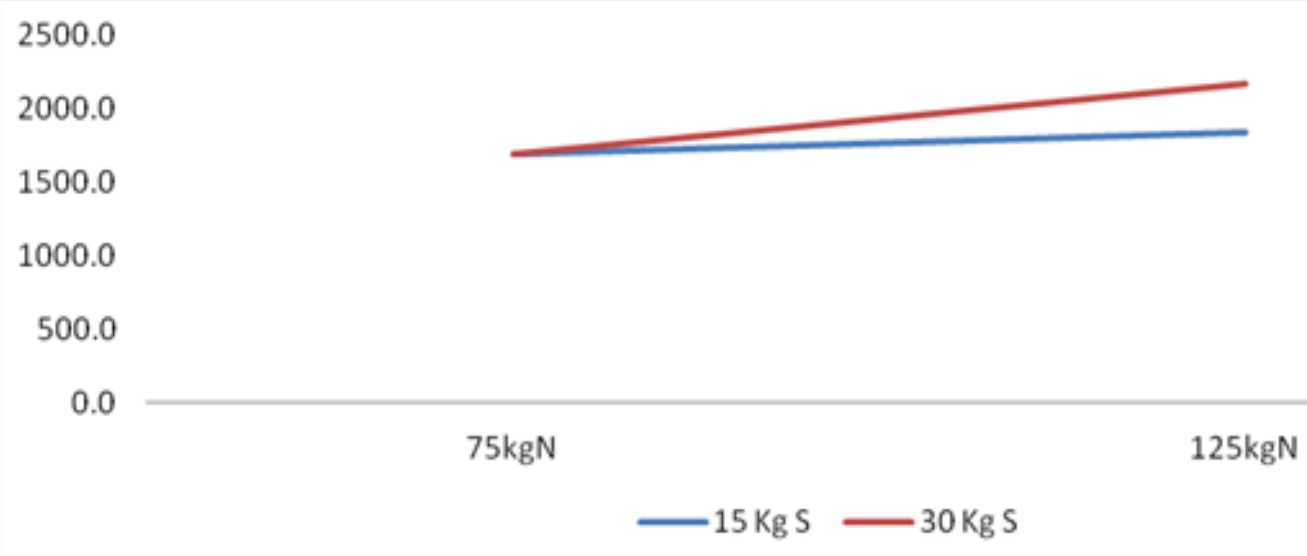

Figure 5. Interaction between sulfur and nitrogen for harvest index of rapeseed 


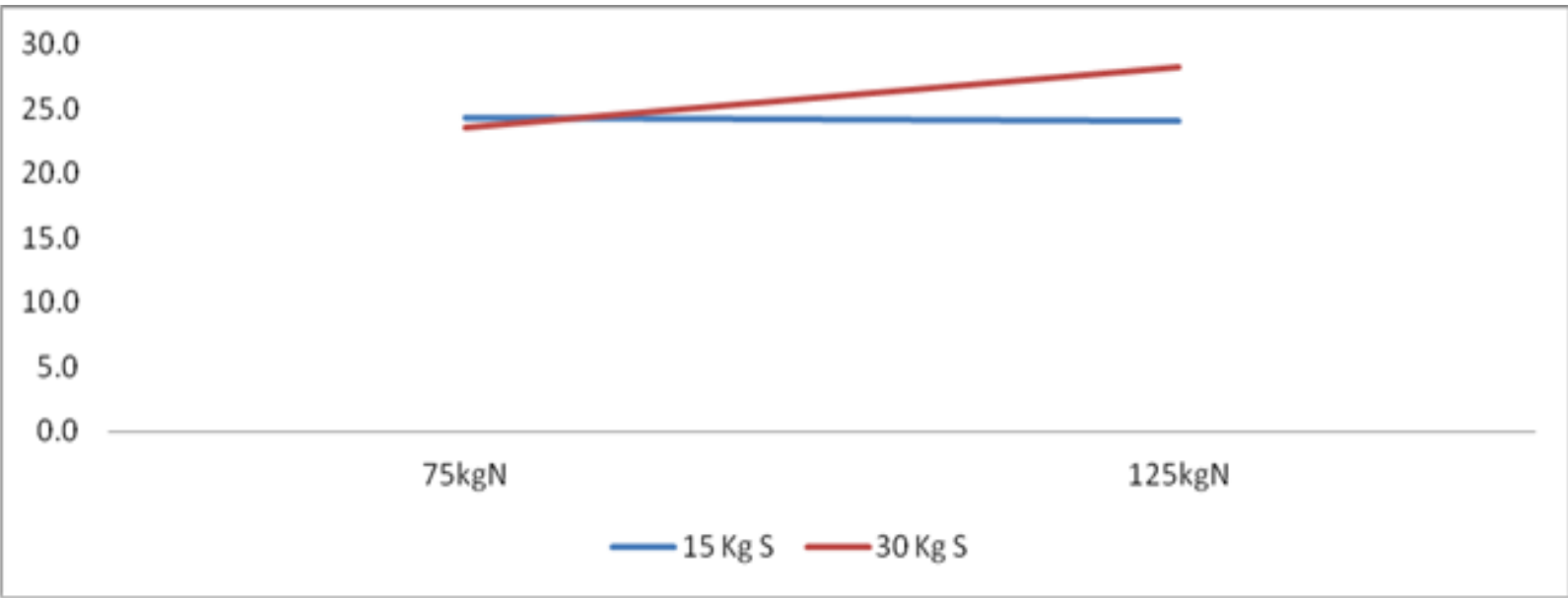

Figure 6. Interaction between sulfur and nitrogen for seed yield of rapeseed

\section{Harvest index (\%)}

Data regarding harvest index of canola as influenced by $\mathrm{N}$ and $\mathrm{S}$ levels are presented in (Table 4). The means values for harvest index revealed that nitrogen levels significantly affect harvest index. Nitrogen and sulfur interaction indicated significant influence on the harvest index. Harvest index of rapeseed was increased from (23.9 to $26.8 \%$ ) with increase in nitrogen from 75 to $125 \mathrm{~kg} \mathrm{~N} \mathrm{ha}^{-1}$. The lower value $(15.9 \%)$ of harvest index was recorded in control plots as compared to the fertilized plots which resulted as the higher value (25.4\%).

\section{Discussion}

Nitrogen (N) and sulfur (S) are basic macronutrients responsible for yield and crop yield may be decreased with their deficiency. Balanced fertilization of these nutrients is one of the basic requirements for higher yield. In this study, we assessed how nitrogen and sulfur fertilization effect weeds infestation and productivity of rapeseed. Weeds density is statistically similar for

Sulfur fertilization but increments in nitrogen application boast the density of some weeds species. Our results authenticate the finding of [8], reported a drastic increase in weeds infestation with nitrogen application. Similarly [9] observed increases in the diversity of herbaceous plant with increments of nitrogen. The higher rate of $\mathrm{S}$ and $\mathrm{N}$ also increases weeds fresh biomass. Higher weeds fresh biomass was recorded in the plots fertilized with maximum $\mathrm{N}$ of $125 \mathrm{~kg} \mathrm{ha}^{-1}$. Possible reason may be with increasing nitrogen plant increases vegetative growth and crop canopy expend. Our results are in agreement with [8] observed higher fresh biomass of weeds with $\mathrm{N}$ application of 120 $\mathrm{kg} \mathrm{ha}{ }^{-1}$. [10] observed maximum fresh biomass of weeds with higher $\mathrm{N}$ application. In contrast [11] concluded that $\mathrm{N}$ could bring significant reduction in weeds infestation due to higher crop growth and development of crop canopy. Weed dry biomass data revealed significant affect of nitrogen, increment in nitrogen enhance the DM accumulation of weeds. This could be explain increasing nitrogen can lead a rapid growth of crop canopy, so ultimately more assimilate accumulation occur which increase dry biomass of weeds. Our results are in line with [10] reported maximum weed dry biomass with higher nitrogen level. In contrast [11] observed that the increments in nitrogen application could bring effective weed control due to swift crop growth. Maximum seed yield of rapeseed was recorded with higher nitrogen and sulfur level. The suitable 
reason for this might be due to the increasing of nitrogen and sulfur the pod plant ${ }^{-1}$ increase and hence seed yield. Our results shows greater resemblance with [12] found enhancement in seed yield with higher $\mathrm{N}$ fertilization. The highest yield were recorded at different rates by some researcher, like [13] obtain highest seed yield at $250 \mathrm{~kg} \mathrm{ha}^{-1}$ $\mathrm{N}$; [14] at $180 \mathrm{~kg} \mathrm{ha}^{-1} \mathrm{~N}$. Biological yield was significantly enhanced with increasing level of both $\mathrm{N}$ and $\mathrm{S}$. The possible reason for the increase in biological yield with the increasing rates of $\mathrm{N}$ may be that $\mathrm{N}$ increases vegetative growth resulting in more assimilate production which increases the growth and development of crop and thus resulted in the increased biological yield. These results are in line with [15] who stated that biological yield increased with increasing rate of $\mathrm{N}$ up to $150 \mathrm{~kg} \mathrm{~N} \mathrm{ha}^{-1}$. With increasing nitrogen rate increased the harvest index, for which the probable reason is that higher availability of nitrogen increases the nutrients uptake. Our results are in line with [16] who stated that increase in $\mathrm{N}$ level resulted in higher harvest index.

\section{Conclusion}

From the results obtained in the study, it is concluded that the higher level of nitrogen and sulfur increase weeds infestation as well as seed yield, biological yield and harvest index of rapeseed, so the optimum rate of both fertilizer should be applied to reduce weed infestation and increase seed yield of rapeseed.

\section{Authors' contributions}

Conceived and designed the experiments: $\mathrm{F}$ Munsif \& S Ullah, Performed the experiments: S Ullah, JE Alam, Analyzed the data: A Ali \& S Ullah, Contributed reagents/ materials/ analysis tools: S Khan, HA Kakar \& R Jalal, Wrote the paper: S Fahad \& S Ullah.

\section{References}

1. MNFS\&R (2011-12). Ministry of National Food Security and Res, Eco Wing, Govt. of Pak, Islamabad.
2. Rathke GW, Christen O \& Diepenbrock W (2005). Effects of nitrogen source and rate on productivity and quality of winter oilseed rape (Brassica napus L.) grown in different crop rotations. Field Crops Res 94: 103-113.

3. Amanullah AZ, Khan A, Jan Z, Shah B, Ahmad SK, Khalil A, Ali, Hidayatullah F, Ahmad \& Nawaz A (2013). Foliar application of nitrogen at different growth stages influence the phonology, growth and yield maize (Zea mays L.). Soil Environ 32(2): 135-140.

4. Ozturk O (2010). Effects of source and rate of nitrogen fertilizer on yield, yield components and quality of winter rapeseed (Brassica napus L.). Chilean J Agri Res 70: 132-141.

5. Al-Barrak KM (2006). Irrigation interval and nitrogen level effects on growth and yield of canola (Rape seed napus L.). Basic Appl Sci 7(1): 87-103.

6. Cheema MA, Malik MA, Hussain A, Shah SH \& Basra SMA (2001). Effects of time and rate of nitrogen and phosphorus application on the growth, seed and oil yields of canola (Brassica napus L.). J Agron Crop Sci 186: 103110.

7. Fathi G, Saeidi AB, Siadat SA \& Ebrahimpour F (2002). Effect of different levels of nitrogen fertilizer and plant density on seed yield of Colza cv. PF 7045 under Khuzestan province conditions. Sci J Agric Ahwaz (Iran) 25: 43-58.

8. Arif M, Ali K, Sirajul Haq M \& Khan Z (2013). Biochar, FYM and Nitrogen increases weed infestation in wheat. Pak J Weed Sci Res 19(4): 411-418.

9. Singh \& Shukla. 2011. Effect of azadirachta indica canopy manipulation and nitrogen fertilization on diversity and productivity of herbicides vegetation in an arid environment of India. Arid Land Res and Manag 25(2): 128-148. 
10. Ali K, Munsif F, Zubair M, Hussain Z, Shahid M, Din IU \& Khan N ( 2011). Management of organic and inorganic nitrogen for different maize varieties. Sarhad J Agric 27(4): 525-529.

11. Hosseini NM, Alizadeh HM \& Ahmadi HM (2006). Effects of Plant Density and Nitrogen Rates on the Competitive Ability of Canola (Brassica napus L.) against weeds. J Agric Sci Technol 8: 281-291.

12. Jackson GD (2000). Effects of nitrogen and sulphur on canola yield and nutrient uptake. Agron J 92: 644-649.

13. Németh T, Máthé Gáspár G, Radimszky L \& Gyori Z (2009). Nitrogen and sulfur content of canola grown on a calcareous chernozem soil. Communi in Soil Sci and Plant Analy 40 (1-6): 825-834.
14. Rabiee M, Kavoosi M \& Kehal PT (2012). Effect of nitrogen fertilizer levels and their application time on yield and some agronomic traits of rapeseed (cv. Hyola 401) in winter cultivation in Gulian. $J$ of Sci and Tec of Agri and Natural Res 15 (58): 199-212.

15. Kutcher HR, Malhi SS, \& Gill KS (2005). Topography and management of nitrogen and fungicide affects diseases and productivity of canola. Agron J 97(2): 533-541.

16. Kardgar V, Delkhoshb B, Noormohammadic G, \& Shiraniradd AH (2010). Effects of nitrogen and plant density on yield of field mustard (Rape seed campestris L.). J of plant Ecophys 2:157-164. 